\title{
Higher Education and Economic Growth of Nigeria: Evidence from Co-integration and Granger Causality Examination
}

\author{
Cordelia Onyinyechi Omodero ${ }^{1} \&$ Kanalechi C.K. Nwangwa ${ }^{1,2}$ \\ ${ }^{1}$ Clifford University Owerrinta, Abia State, Nigeria \\ ${ }^{2}$ Commissioner of Education, Abia State, Nigeria \\ Correspondence: Cordelia Onyinyechi Omodero, Clifford University Owerrinta, Abia State, Nigeria.
}

Received: February 6, 2020

Accepted: March 21, 2020

Online Published: March 23, 2020

doi:10.5430/ijhe.v9n3p173

URL: https://doi.org/10.5430/ijhe.v9n3p173

\begin{abstract}
This study investigates the level of co-integration between education and economic growth in Nigeria and the causality effect of education on economic growth. The study employs secondary form of data spanning from 2000 to 2018 and are sourced from UNESCO, World Bank and CBN statistical bulletin. The data are collected on GDP, education expenditure and gross enrolment ratio of higher education for the period under review. The study uses Johansen co-integration and Granger causality tests for analysis and the findings show that education and economic growth in Nigeria have a long term co-integration while Granger causality test reveals that education and gross enrolment ratio of higher education are not affecting economic progress and the GDP is not influencing both of them too. The implication is that if Nigeria's educational system continues the way it is presently, it will remain a long term problem and will continue to negatively affect economic growth. Other countries will be benefiting from modern technologies through improvement on their educational system, but Nigeria may not be at the same pace if immediate policy changes in favor of education are not embraced. Thus, the study suggests major improvement on government's annual budgets for education in order to decrease the population of out-of-school children and increase the stock of skilled human capital in the country.
\end{abstract}

Keywords: higher education, educational finance, economic growth, gross enrolment, GDP

JEL Classification codes: D83, I22, I23, O40.

\section{Introduction}

Education is a method by which the basic information and knowledge are obtained through the means of tutoring and book studying. Education provides access to skills and knowledge necessary to adapt an economy to new technologies that boost economic growth (Odit, Dookhan \& Fauzel, 2010). The expenses on training can produce superior workforce which can efficiently and economically put modern technology into use in any form of production process (Mallick, Das \& Pradhan, 2016). Odit et al. (2010) submit that education has been observed as a human capital investment leading to a lifelong paybacks accruing to the learned person. Investment in education as seen in several nations, has been the principal and most important goal of administrations in order to enhance the superiority of social assets and increase the skilled labor force necessary for economic advancement. Education in all ramifications is an asset (Abubakar, 2014), thus, it behooves on nations to greatly invest in education so as to derive its maximum benefits which aid economic development and sustainability (Adetula, Adesina, Owolabi \& Ojeka, 2017). Based on this background, various scholars (Blankenau, 2005; Blankenau \& Simpson, 2004; Kaganovich \& Zilcha, 1999; Glomm \& Ravikumar, 1992, 1998) contend that there is an unswerving consequence of investments in education on economic growth. On the contrary, researchers such as (Bouzahzah et al., 2002; Brauninger \& Vidal, 1999; Hendricks, 1999; Milesi-Ferretti \& Roubini, 1998; Zhang, 1996) dispute that learning investment actually influence fiscal expansion. As for positive correlation existence amid administration overheads in training and fiscal progress, studies by (Baro \& Salai-Martin, 1995; Cullison, 1993) provided a positive corroborating evidence, but Levin and Renelt (1992) found a conflicting result which established absence of nexus amid government overheads in training and economic evolution.

An educated work force is far better in influencing fiscal evolution as well as capacity building of a nation. It has been discovered that wealth, labor, and technological know-how cannot distinctly form the fiscal expansion components but rather, it is proven that education emerges as the principal dynamic force that drives fiscal progress 
(Solow, 1956). Denison (1967) is one of the earlier economic innovators who stressed that the learning effect on fiscal growth is essentially remarkable. As explained by Lucas (1967), human asset is one of the most important elements of economic progress as expounded by endogenous growth model.

Lucas (1967) further submits that the growth of human asset is only probable through educational development, due to its positive influence on labor efficiency. Education is the only means of increasing the worth of human beings in a nation in order to produce a trained, well-informed and vigorous labor force that can offer solution to a nationwide economic difficulty on a continual basis (Omodero, 2019). Thus, the attainment of economic liberation and advancement of a country is dependent on the educational level of the labor force and policy makers of that country (Adetula, Adesina, Owolabi \& Ojeka, 2017). It has been validated that fiscal progression and education are favorably interconnected (Barro, 1991). The connection between human capital and economic improvement method has been comprehensively scrutinized (Romar, 1990; Rebelo, 1991; Grossman and Helpman, 1991; Barro, 1991) thus, there is proof of a positive relationship amid training and fiscal progression.

It is observed that a higher importance attached to training, lead to its greater impact on a nation's fiscal progress (Kotaskova, Prochazka, Smutka, Maitah, Kuzmenko, Kopecka \& Honig, 2018). Education is regarded as exceptionally substantial constituent of economic expansion (Ali \& Jabeen, 2015). Due to the need to foster economic growth in emerging countries such as Nigeria, the improvement on learning as well as the associated benefits in order to achieve this objective will be favorably anticipated. However, in Nigeria education has not been given the priority attention it deserves. The frequent Academic Staff Union of Universities (ASUU) strike and the level of out-of-school children are very disheartening and pointers that investment in Nigeria's education is still very low. Nigeria's budgetary expenditure on education is not sufficient to suppress the broadening gap where only seven percent of Nigeria's \$24 billion 2018 budget is set aside for education, and it seems that new policies to improve expenditure on education is still improbable (VOANEWS, December 11, 2018). An investigation piloted by the United Nations Children's Fund (UNICEF) points out that the population of out-of-school children in Nigeria has increased from 10.5 million to 13.2 million which appears to be the highest in the world (Adedigba, 2018; VOANEWS, December 11, 2018). Nigeria accounts for more than one in five out-of-school children and 45 percent of out-of-school children in West Africa (Adedigba, 2018). The yearly gross enrollment ratio (GER) as captured by (UNESCO, 2019) shows that the ratio of out-of-school children (OSR) in Nigeria is by far greater than the ratio of children in school (see table 1 below). The implication is that, there is the danger of having a longer term illiterate community in the future who will not know the value of education and may not find the reason to educate their children even to the unborn generation, than a literate social group that can promote education by investing in their children's education. 
Table 1. Ratio of children in school and out of school

\begin{tabular}{ccc}
\hline YEAR & GER & OSR \\
& $\%$ & $\%$ \\
\hline 2000 & 24.61 & 75.39 \\
2001 & 27.03 & 72.97 \\
2002 & 29.61 & 70.39 \\
2003 & 31.23 & 68.77 \\
2004 & 35 & 65 \\
2005 & 34.96 & 65.04 \\
2006 & 34.46 & 65.54 \\
2007 & 31.87 & 68.13 \\
2008 & 35.39 & 64.61 \\
2009 & 39.23 & 60.77 \\
2010 & 44.22 & 55.78 \\
2011 & 45.56 & 54.44 \\
2012 & 47.18 & 52.82 \\
2013 & 56.21 & 43.79 \\
2014 & 45.62 & 54.38 \\
2015 & 46.78 & 53.22 \\
2016 & 42 & 58 \\
2017 & 47.01 & 52.99 \\
2018 & 43.02 & 56.98 \\
\hline
\end{tabular}

Source: World Bank, UNESCO Institute for Statistics, Authors' calculation, 2020

GER= Gross Enrolment Ratio; OSR=Out-of-School Children Ratio

The most prevalent states affected by the out-of-school children include: Kano, Akwa Ibom, Katsina, Kaduna, Taraba, Sokoto, Yobe, Zamfara, Oyo, Benue Jigawa and Ebonyi states (Aluko, 2019). According to the wife of the President (Mrs. Aisha Buhari) the number of children that are not in school in the Northern part of Nigeria is very frightening, especially the girl children, due to economic challenges and socio-cultural norms that are being observed (Hindi, 2020). In this circumstance, it is observable that the girl children are more vulnerable and affected, as a result the wife of the President expressed that "The case is most disheartening in the northern states where insurgency, poverty and our socio-cultural norms have played key roles in further worsening what is left of the ruins of dilapidated structures, insufficient and poorly motivated teachers at all levels" (Hindi, 2020). However, this study aims at providing empirical evidence on the causality effect of higher education on economic growth and the type of relationship existing between them. Nevertheless, there is a significant enquiry as whether there is a connection between education and economic progress in Nigeria, and if there is, to what extent. In order to carry out this investigation and to achieve this research objective, gross domestic product (GDP) will be employed to represent fiscal progression while explanatory variables will be the gross enrolment ratio and government expenditure on education in Nigeria.

\section{Literature Review}

\subsection{Conceptual Issue}

\subsubsection{Gross Enrollment Ratio}

Gross enrollment ratio is the percentage of total school registration of children, regardless of age, to the population of the age group that officially corresponds to the level of education (Factfish, 2020). Secondary education concludes the running of basic education that commences at the primary level, and targets to provide the basics for lasting knowledge and human development, by offering more subject and skill-oriented tutoring using more expert 
educators (Factfish, 2020). Gross Enrolment Ratio (GER) or Gross Enrolment Index (GEI) is a numerical device or technique officially "employed in the education sector and by the UN in its Education Index, to determine the number of students registered in school at numerous diverse grade levels (like elementary, middle school and high school), and use it to indicate the ratio of the population of students who reside in that country to those who meet the requirements for the particular grade level. The United Nations Educational, Scientific and Cultural Organization (UNESCO), defines "Gross Enrolment Ratio" as the aggregate registration within a nation in a particular level of education, irrespective of age, expressed as a percentage of the population in the official age group corresponding to this level of education" (UNESCO, 2019). "The GER can be over 100\% as it includes students who may be older or younger than the official age group" (UNESCO, 2019).

\subsection{Theoretical Review}

It is no longer implausible that enhancements in education are interrelated with long run economic expansion. The three general theories emphasizing on the influences of education on economic progression include: the basic human capital approach, the modernization method and the knowledge transfer approach. The human capital approach is a theory which states that education generally enhances the expertise and capabilities of a nation's workforce, most essentially for better productivity and enhanced skills required for the present-day technology, necessary for economic growth improvement (Earle, 2010). The modernization method links education to improvement on economic capacity through development of new concepts and technological know-hows (Earle, 2010). The knowledge transfers approach states that education is the channel through which all relevant information and the knowledge required to apply new concepts and technologies are disseminated (OECD, 2010). In summary, education has an important role in the growth of a country's economy. It accomplishes its task by providing qualitative and quantitative labor force needed in the course of a country's economic expansion, while on the other hand, with its creation and diffusion of information utility, it inspires nations to follow and develop modern manufacturing technologies and to transmit them to the manufacturing process (Mercan \& Sezer, 2014). According to Mercan and Sezer (2014), the level of education is the major cause of the disparities noticed in the economic performance of the advanced and emerging countries.

\subsection{Empirical Review}

Hussaini (2020) made use of econometric panel co-integration examination to investigate the long term correlation between upper schooling and fiscal progress of the South Asian states. The study established affirmative extensive connection amid the South Asian nations' fiscal progress and total high school registration percentage. Thus, the study concluded that the South Asian nations could enhance the quality of human capital needed for economic growth if they would pay more serious attention to higher education. Valero and Reenen (2019) considered if Universities exert influence on fiscal progression using group raw figures of 15,000 Universities in 78 countries. The study data spanned from 1950 to 2010 and the findings revealed the existence of positive correlation amid imminent progress in GDP per capita and the growth in the population of Universities. The study further found positive spillover effects of universities from other geographical areas on nearby states. It is believed that education is a poverty alleviation tool, however, Omodero (2019) study on the effect of government sectoral expenditure on poverty lessening in Nigeria, found evidence that government expenses on education and other major economic sectors did not have material influence on poverty reduction agenda.

Kotaskova et al. (2018) examined the relationship between education and economic growth in India from1975 to 2016 using Granger Causality and Co-integration methods. The study concentrated in primary, secondary and tertiary levels of education and found the existence of a positive link between different levels of education and economic growth in India. Hassan and Rafaz (2017) made use of simple ordinary least squares method to assess the impact of female education on the economic growth of Pakistan for a period covering 1990 to 2016. The result showed that $1 \%$ rise in female education, female labor force involvement, education spending and fertility rate give rise to $96 \%$ growth in Pakistan GDP. The result provided evidence that female education had a positive noteworthy impact on economic growth of Pakistan. The study suggested that the government should apportion more resources to promote female education in Pakistan.

Adetula et al. (2017) stressed on the paybacks of investment in education for Nigeria's economic development using ordinary least squares (OLS) regression method. The study found evidence that education sector contributed substantially to economic development of Nigeria but had not received adequate funding that could enhance annual gross enrollment rate, both at the primary, secondary and higher education level. In other words, the study corroborated the fact that government spending on Nigeria's educational system is still not sufficient to reduce the growing population of the out-of-school children in the country. Alsanousi (2017) studied the relationship between higher education quality and economic growth of Libya, the findings revealed that higher education and economic growth of 
Libya had a very strong relationship. The study further indicated that higher education had a high degree of contribution to economic growth of Libya.

Mallick, Das and Pradhan (2016) verified the impact of educational expenditure on economic growth of 14 major Asian Countries. The study spanned from 1973 to 2012 using full modified ordinary least squares method which produced the result that investment in education impacted positively on the economic growth of the 14 major Asian countries. In another study, Mallick and Dash (2015) applied co-integration and granger causality econometric tests to examine the extent to which education affected economic growth in India from 1951 to 2012. The findings showed that education granger caused economic growth while a long run relationship was established. Mercan and Sezer (2014) investigated the effect of education expenditure on economic growth of Turkey using data that ranged from 1970 to 2012. The study found a positive relationship between education expenses and economic growth. Thus the evidence proved that investment in education in Turkey had a significant positive effect on economic growth.

Reza and Widodo (2013) employed panel data ranging from 1996 to 2009 to investigate the impact of education on economic growth of Indonesia. The study revealed that $1 \%$ increase in average education per worker would lead to about $1.56 \%$ increase in productivity. The result implied that education per worker in Indonesia had a significant positive impact on economic growth of the country. Odit et al. (2010) investigated the impact of investment in education on economic growth of Mauritius using Cobb-Douglas Production function. The study covered a period from 1990 to 2006 and the findings revealed that human capital impacted positively and significantly on economic growth. The study confirmed that investment in educating the Country's work force was beneficial to Mauritius economy.

\section{Methodology}

The study employs descriptive research design which permits numerical gathering of research data on selected variables for statistical analysis. The secondary form of data employed for this study span from $2000-2018$ and are gathered from UNESCO, World Bank and the Central Bank of Nigeria (CBN) Statistical Bulletin 2018 edition. The data are collected on GDP (proxy for economic growth), expenditure on education and gross enrollment ratio. Relevant diagnostic tests are performed while Johanson Co-integration and Granger causality analyses are carried out to establish the extent of co-integration and causality effects of the variables respectively. Thus, the model is specified as follows:

$$
G D P=f(E D U, G E R)
$$

This is mathematically stated as follows:

$$
L O G G D P=\beta_{0}+\beta_{1} L O G E D U+\beta_{2} L O G G E R+\varepsilon
$$

Where:

GDP-Gross Domestic Product

EDU-Expenditure on Education

GER-Gross Enrollment Ratio

$\varepsilon$-Error term

$\beta 1$ - $\beta 2$-Coefficients of the independent variables.

A Prior Expectation:

$\beta 1-\beta 2>0$

The prior economic expectation is that all the predictor variables (EDU \& GER) should be greater than zero which implies positive contribution to GDP. 


\section{Data Analysis and Interpretation}

Table 2. Stability test

Ramsey RESET Test

Equation: UNTITLED

Specification: LOG_GDP LOG_EDU LOG_GER C

Omitted Variables: Squares of fitted values

\begin{tabular}{cccc}
\hline & Value & Df & Probability \\
\hline t-statistic & 1.875243 & 15 & 0.0804 \\
F-statistic & 3.516537 & $(1,15)$ & 0.0804 \\
\hline
\end{tabular}

Source: Authors' calculation, 2020

The Ramsey Reset test on Table 2 is applied to determine the presence of any significant nonlinear relationships in the model. The result indicates that the p-value is $0.08>0.05$, thus there is absence of nonlinear relationship in the model.

Table 3. Serial correlation LM test

Breusch-Godfrey Serial Correlation LM Test:

\begin{tabular}{cccc}
\hline & & \\
\hline F-statistic & 1.079546 & Prob. F(2,14) & 0.3664 \\
Obs*R-squared & 2.538678 & Prob. Chi-Square(2) & 0.2810 \\
\hline
\end{tabular}

Source: Authors' calculation, 2020

The result of Breusch-Godfrey Serial Correlation LM Test on Table 3 shows that there is no existence of serial correlation in this model as the probability value of LM test is 0.3664 which if greater than $5 \%$ required level of significance.

Table 4. Heteroskedasticity Test

Breusch-Pagan-Godfrey

\begin{tabular}{cccc}
\hline & & & \\
\hline F-statistic & 0.220615 & Prob. F(2,16) & 0.8044 \\
Obs*R-squared & 0.509898 & Prob. Chi-Square(2) & 0.7750 \\
Scaled explained SS & 0.209253 & Prob. Chi-Square(2) & 0.9007 \\
\hline
\end{tabular}

Source: Authors' calculation, 2020

The test for heteroscedasticity on Table 4 indicates that the probability value is 0.8 which is greater than $5 \%$ acceptable level. In this case the null hypothesis stating that there is existence of heteroscedasticity in the model is rejected, thus, the model is not heteroscedastic.

Table 5. Multicollinearity test

Variance Inflation Factors

Date: 01/15/20 Time: 14:42

Sample: 20002018

Included observations: 19

Source: Authors' calculation, 2020

\begin{tabular}{cccc}
\hline Variable & $\begin{array}{c}\text { Coefficient } \\
\text { Variance }\end{array}$ & $\begin{array}{c}\text { Uncentered } \\
\text { VIF }\end{array}$ & $\begin{array}{c}\text { Centered } \\
\text { VIF }\end{array}$ \\
\hline LOG_EDU & 0.024316 & 238.6887 & 5.121135 \\
LOG_GER & 0.305423 & 1489.922 & 5.121135 \\
C & 0.340943 & 662.8046 & NA \\
\hline
\end{tabular}


The variance inflation factor (VIF) on table 5 is used to identify the existence of multicollinearity among the predictor variables, when VIF is above the value of 10 . The VIF of all the explanatory variables used in this study are all below ten (10) and so, there is absence of multicollinearity in the model.

Normality test

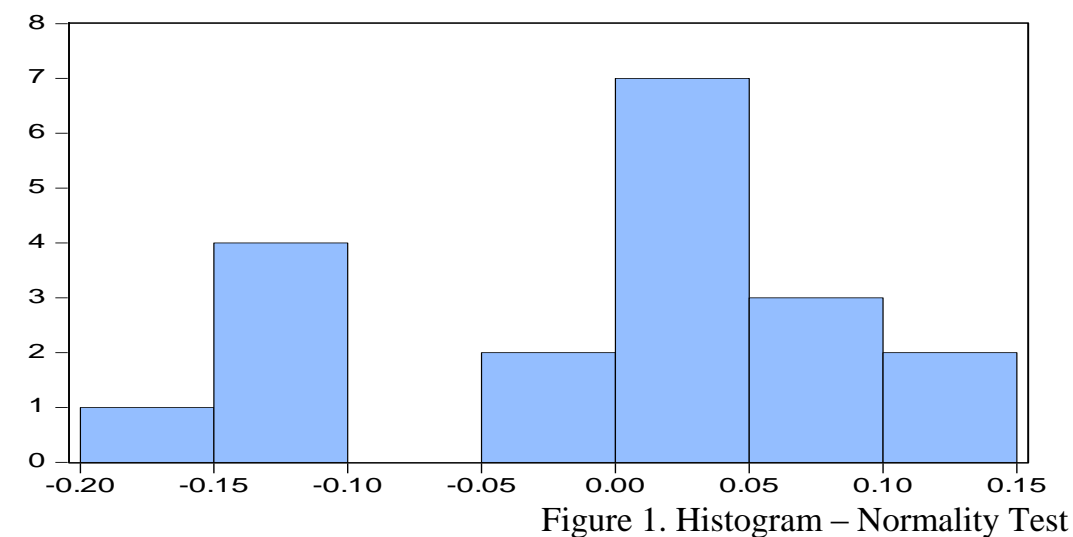

\begin{tabular}{|lr|}
\hline Series: Residuals \\
Sample 2000 2018 \\
Observations & 19 \\
& \\
Mean & $4.22 e-16$ \\
Median & 0.035991 \\
Maximum & 0.126819 \\
Minimum & -0.178166 \\
Std. Dev. & 0.093207 \\
Skewness & -0.719815 \\
Kurtosis & 2.157406 \\
& \\
Jarque-Bera & 2.202811 \\
Probability & 0.332404 \\
\hline
\end{tabular}

Source: E-views version 9 output

In Figure 1 below, the Jarque-Bera statistics is used to test for the normality of the model. The Jarque-Bera p-value of $0.33>0.05$, thus, there is a normal distribution. The standard deviation shows that the distribution has a lower spread since it is far below the mean value. It is also negatively skewed and the kurtosis is 2.157.

Table 6. Co-integration rank test

Date: 01/15/20 Time: $16: 15$

Sample (adjusted): 20022018

Included observations: 17 after adjustments

Trend assumption: Linear deterministic trend

Series: LOG_GDP LOG_EDU LOG_GER

Lags interval (in first differences): 1 to 1

Unrestricted Cointegration Rank Test (Trace)

\begin{tabular}{ccccc}
\hline $\begin{array}{c}\text { Hypothesized } \\
\text { No. of CE(s) }\end{array}$ & Eigenvalue & $\begin{array}{c}\text { Trace } \\
\text { Statistic }\end{array}$ & $\begin{array}{c}0.05 \\
\text { Critical Value }\end{array}$ & Prob.** \\
\hline None $*$ & 0.716232 & 33.14843 & 29.79707 & 0.0198 \\
At most 1 & 0.430967 & 11.73524 & 15.49471 & 0.1701 \\
At most 2 & 0.118818 & 2.150342 & 3.841466 & 0.1425 \\
\hline
\end{tabular}

Trace test indicates 1 cointegrating eqn(s) at the 0.05 level

* denotes rejection of the hypothesis at the 0.05 level

** MacKinnon-Haug-Michelis (1999) p-values

Source: Authors' calculation, 2020

Johansen co-integration test results indicates that education and economic growth in Nigeria have a long-term relationship. What it implies is that if the Nigerian educational system continues as it is presently, the negative effect on economic growth will be a long term challenge and will require a long-term remedial process to restore it to normalcy. That means, the less attention paid to education will continue to subject the country to economic upheavals until the policy makers will realize the importance of education and give it its priority attention. 
Table 7. Pairwise Granger Causality Tests

Date: 01/15/20 Time: $16: 13$

Sample: 20002018

Lags: 2

\begin{tabular}{cccc}
\hline Null Hypothesis: & Obs & F-Statistic & Prob. \\
\hline LOG_EDU does not Granger Cause LOG_GDP & 17 & 2.91037 & 0.0932 \\
LOG_GDP does not Granger Cause LOG_EDU & & 2.33368 & 0.1393 \\
LOG_GER does not Granger Cause LOG_GDP & \multirow{2}{*}{17} & 0.56349 & 0.5836 \\
LOG_GDP does not Granger Cause LOG_GER & & 0.53101 & 0.6012 \\
LOG_GER does not Granger Cause LOG_EDU & \multirow{2}{*}{17} & 0.55519 & 0.5880 \\
LOG_EDU does not Granger Cause LOG_GER & & 0.75840 & 0.4896 \\
\hline
\end{tabular}

Source: Authors' calculation, 2020

By summing up the results of the Granger causality test, the results show that expenditure on education (EDU) does not Granger cause the GDP at 5\% level of significance and the GDP also does not Granger cause EDU because the probability values ( 0.09 and 0.14 respectively) are insignificant. Thus, there is a unidirectional relationship existing between EDU and the GDP. Similarly, Gross Enrollment Ratio (GER) does not Granger cause economic growth (GDP) at 5\% level of significance and the GDP does not Granger cause GER as the p-values $(0.58$ and 0.60 correspondingly) are greater than 0.05 , thus implying that they are both immaterial. The result also shows that GER does Granger cause EDU and EDU does not Granger cause GER at 5\% level of significance. So, there is unidirectional relationship existing between EDU and GER. Expenditure on education does not encourage children enrollment in schools. The growth in GDP does not also positively influence education and so unidirectional relationship exists.

\section{Conclusion and Recommendation}

\subsection{Conclusion}

In this research, the target is to establish the type of co-integration existing amid education and fiscal progression of Nigeria and its causality effects. It is concluded on the basis of Johansen Co-integration test results that there exists a long run co-integration between education and economic growth. However, the Pairwise Granger Causality Tests reveal that expenditure on education and higher education gross enrollment ratio in Nigeria do not have causality effect on economic growth and vice versa. These empirical findings have validated the fact that investment in education in Nigeria is too insignificant. The number of children that are not in school outnumber the population of children in school enrollment. In other words, the level of illiteracy is rapidly and negatively affecting economic growth.

\subsection{Recommendation}

Based on these findings, this study is proposing that the nation's policies have to be prioritized on the enhancements of various institutions of higher learning in order to boost economic growth. The government should make such policies which could improve high-quality education for all, and it would be only efficacious when the government increases the overheads on the education sector in Nigeria. More emphatically, high quality education should be made less expensive for all through government funding of major education materials and equipment. The suggested effort to improve the expenditure on education so as to encourage availability of learning opportunity for all, Idrees and Muhammad (2013) submit that the population of educated human capital will definitely increase. Therefore, due to the fundamental need for more investment in education in Nigeria, this study is suggesting that the government should consider spending on education the first to been given priority attention in all annual budgets. The case of insurgency affecting school enrollment especially in the northern part of the country should be properly addressed by increasing security forces' operations in the northern region.

\section{References}

Abubakar, B.A. (2014). Education and sustainable national development in Nigeria: Challenges and way forward. International Letters of Social and Humanistic Sciences, 19, 25-37.

Adedigba, A. (2018). Nigeria now has 13.2 million out of school children - UBEC. Retrieved on January 15, 2020 
from:

https://www.premiumtimesng.com/news/top-news/288344-nigeria-now-has-13-2-million-out-of-school-childre n-ubec.html.

Adetula, D., Adesina, K., Owolabi, F., \& Ojeka, S. (2017). Investment in education for the Nigerian economic development. Journal of Internet Banking and Commerce, 22(1), 1-15.

Ali, H., \& Jabeen, A. (2015). Effects of education on economic growth: Evidence from Pakistan. American Journal of Economics, Finance and Management, 1(6), 579-585.

Alsanousi, A.M.A. (2017). The effect of higher education quality on economic growth in Libya. International Journal of Academic Research in Business and Social Sciences, 7(3), 139-149. http://dx.doi.org/10.6007/IJARBSS/v7-i3/2706

Aluko, O. (2018). Nigeria has 10.2 million out-of-school children, FG says. Retrieved on January 15, 2020 from: https://punchng.com/nigeria-has-10-2million-out-of-school-children-fg-says/.

Barro, R.J. (1991). Economic Growth in a Cross-Section of Countries. Quarterly Journal of Economics, 106, 407-443. https://doi.org/10.2307/2937943

Barro, R.J., \& Salai-Martin, X. (1995). Economic Growth. McGraw-Hill. New York.

Blankenau, W.F. (2005). Public Schooling, College Subsidies and Growth. Journal of Economic Dynamics and Control, 29, 487-507. https://doi.org/10.1016/j.jedc.2004.04.001

Blankenau, W.F., \& Simpson, N.B. (2004). Public education expenditures and growth. Journal of Development Economics, 73, 583-605. https://doi.org/10.1016/j.jdeveco.2003.05.004

Bouzahzah, M., De la Croix, D., \& Docquier, F. (2002). Policy Reforms and Growth in Computable OLG Economies. Journal of Dynamics and Control, 26, 2093-2113. https://doi.org/10.1016/S0165-1889(01)00023-9

Brauninger, M., \& Vidal, J.P. (1999). Private versus public financing of education and endogenous Growth. Journal of Population Economics, 13, 387-401. https://doi.org/10.1007/s001480050143

Cullison, W. (1993). Public investment and economic growth. Federal Reserve Bank of Richmond Economic Quarterly, 79, 19-33.

Denison, E. (1967). Why growth rates differ? The Brookings Institution.

Earle, D. (2010). How can tertiary education deliver better value to the economy? Tertiary Education deliver better value to the economy? Tertiary education occasional paper 2010/08. Available online at: www.educationcounts.govt.nz.

Factfish. (2020). Nigeria: Gross enrolment rate, secondary, total (\%). Retrieved on February 1, 2020 from: http://www.factfish.com/statistic-country/nigeria/gross+enrolment+rate,+secondary,+total.

Glomm, G., \& Ravikumar, B. (1992). Public versus private investment in human capital: Endogenous growth and income inequality. Journal of Political Economy, 100, 818-834. https://doi.org/10.1086/261841

Glomm, G., \& Ravikumar, B. (1998). Flat-rate taxes, government spending on education and Growth. Review of Economic Dynamics, 1, 306-325. https://doi.org/10.1006/redy.1997.0001

Grossman, G.M., \& Helpman, E. (1991). Innovation and Growth in the Global Economy. MIT Press. Cambridge. MA.

Hassan, S.A., \& Rafaz, N. (2017). The role of female education in economic growth of Pakistan: A time series analysis from 1990-2016. International Journal of Innovation and Economic Development, 3(5), 83-93. https://doi.org/10.18775/ijied.1849-7551-7020.2015.35.2007

Hendricks, L. (1999). Taxation and long-run growth. Journal of Monetary Economics, 43, $411-434$. https://doi.org/10.1016/S0304-3932(98)00058-0

Hindi, L.Y. (2020). North's Out-of-School children population disheartening - Aisha Buhari. Retrieved from: https://punchng.com/norths-out-of-school-children-population-disheartening-aisha-buhari/ on March 17, 2020.

Hussaini, N. (2020). Economic growth and higher education in South Asian. International Journal of Higher Education, 9(2), 118-125. https://doi.org/10.5430/ijhe.v9n2p118

Idrees, A.S., \& Muhammad, W.S. (2013). Does Public Education Expenditure Cause Economic Growth? Comparison of Developed and Developing Countries. Pakistan Journal of Commerce and Social Sciences, 7 , 
174-183.

Kaganovich, M., \& Zilcha, I. (1999). Education, social security and growth. Journal of Public Economics, 71, 289-309. https://doi.org/10.1016/S0047-2727(98)00073-5

Kotaskova, S.K., Prochazka, P., Smutka, L., Maitah, M., Kuzmenko, E., Kopecka, M., \& Honig, V. (2018). The implication of education on economic growth: The case of India. Acta Universitatis Agricultural et Silviculturae Mendelianae Brunensis, 66(1), 253-262. https://doi.org/10.11118/actaun201866010253

Levine, R., \& Renelt, D. (1992). A sensitivity analysis of cross-country growth regressions. The American economic review, 1992, 942-963.

Lucas, R.E. (1967). Adjustment costs and the theory of supply. The Journal of Political Economy, 1967, $321-334$. https://doi.org/10.1086/259289

Mallick, L., \& Dash, D.P. (2015). Does expenditure on education affect economic growth in India? Evidence from co-integration and granger causality analysis. Theoretical and Applied Economics, 22(4), 63-74.

Mallick, L., Das, P.K., \& Pradhan, K.C. (2016). Impact of educational expenditure on economic Growth in major Asian Countries: Evidence from econometric analysis. Theoretical and Applied Economics, 23(2), 173-186.

Mercan, M., \& Sezer, S. (2014). The effect of education expenditure on economic growth: The Case of Turkey. Procedia - Social and Behavioural Sciences, 109(2014), 925-930. https://doi.org/10.1016/j.sbspro.2013.12.565

Milesi-Ferretti, G., \& Roubini, N. (1998). On the taxation of human and physical capital in models of endogenous growth. Journal of Public Economics, 70, 237-254. https://doi.org/10.1016/S0047-2727(98)00036-X

Odit, M.P., Dookhan, K., \& Fauzel, S. (2010). The impact of education on economic growth: The Case of Mauritius. International Business \& Economics Research Journal, 9(8), 141-152. https://doi.org/10.19030/iber.v9i8.620

Organization for Economic Co-operation and Development. (2010). The high cost of low Educational performance: the long-run economic impact of improving PISA outcomes, Paris: OECD.

Omodero, C.O. (2019). Government sectoral expenditure and poverty alleviation in Nigeria. Research in World Economy, 10(1), 80-90. https://doi.org/10.5430/rwe.v10n1p80

Omodero, C.O. (2019). Government general spending and human development: A case study of Nigeria. Academic Journal of Interdisciplinary Studies, 8(1), 51-59. https://doi.org/10.2478/ajis-2019-0005

Rebelo, S.T. (1991). Long Run Policy Analysis and Long Run Growth. Journal of Political Economy, 99, $500-521$. https://doi.org/10.1086/261764

Reza, F., \& Widodo, T. (2013). The impact of education on economic growth in Indonesia. Journal of Indonesian Economy and Business, 28(1), 23-44.

Solow, R.M. (1956). A contribution to the theory of economic growth. The Quarterly Journal of Economics, 1956, 65-94. https://doi.org/10.2307/1884513

Ugbogbo H.E., Akwemoh, M.O., \& Omoregie, C.B. (2013). The Role and Challenges of Education in National Development (The Nigerian Experience). Journal of Educational and Social Research, 3, 25-30. https://doi.org/10.5901/jesr.2013.v3n10p25

UNESCO Institute for Statistics. (2019). Nigeria - School enrollment, tertiary (\% gross). Available online at: http://uis.unesco.org/

Valero, A., \& Reenen, J.V. (2019). The economic impact of Universities: Evidence from across The globe. Economics of Education Review, 68(2019), 53-67. https://doi.org/10.1016/j.econedurev.2018.09.001

VOANEWS. (2018). UN: In Nigeria more than 13 Million School-age Children out of School. Retrieved on January 15, 2020 from: https://www.voanews.com/africa/un-nigeria-more-13-million-school-age-children-out-school

Zhang, J. (1996). Optimal public investment in education and endogenous growth. Scandinavian Journal of Economics, 98, 387-404. https://doi.org/10.2307/3440733 